American Journal of Agricultural and Biological Sciences 6 (1): 99-104, 2011

ISSN 1557-4989

(C) 2010 Science Publications

\title{
The Role of Extension in Adopting Solar Energy in Rural Areas Case of Carbon Sequestration Project
}

\author{
${ }^{1}$ Seyed Jamal F. Hosseini and ${ }^{2}$ Zahra Soltani \\ ${ }^{1}$ Department of Agricultural Extension and Education, Science and Research Branch, \\ Islamic Azad University, Tehran, Iran \\ ${ }^{2}$ Department of Agricultural Extension and Education, Birjand Branch, \\ Islamic Azad University, Birjand, Iran
}

\begin{abstract}
Problem statement: Solar energy as a renewable energy source is considered as an important alternative options for farmers. The development of renewable energy in rural areas faces several challenges. Agricultural extension by its nature has an important role in promoting the adoption of new technologies and innovations. Approach: The main focus of this study is to find out the role of extension in adopting solar energy in rural areas by participants in carbon sequestration project. A questionnaire was developed and data was collected from 310 participants in carbon sequestration project. Regression analysis was used to analyze the data. The stepwise method was used in the regression analysis. Results: The result indicates that $30 \%$ of the variance in the perception of respondents about role of extension in adopting solar energy could be explained by using educational films and slides, contacting with extension agents, visiting sample sites and providing lectures. Conclusion and Recommendations: The results demonstrated that success of solar energy will depend on the informing population about benefits and in this regard the authorities should provide accurate and on time information. There is no single and appropriate intervention for developing and protecting solar energy in rural areas and in view of the numerous and varied constraints and opportunities, there is need to develop location- specific strategies.
\end{abstract}

Key words: Adopting solar energy, demographic variables, Renewable Energy Technology (RET), analytical methods, socio-economic development, educational films, independent variables, carbon sequestration project, regression analysis, photovoltaic systems

\section{INTRODUCTION}

Rural energy is generally recognized as an important element of rural socio-economic development, not as an end in itself, but through the demand for the services made possible through energy inputs, such as potable water pumping, extension of the day by lighting and cooking. As a general trend, an increasing energy demand-both in quantity and qualityis highly correlated with socio-economic development. Yet, the rural populations of many developing countries have been excluded from most of the benefits of economic development and the transition to better (quality) energy services (Van Campen et al., 2000).

Renewable energy is considered to be the basis for sustainable energy supply systems. Population growth, key incidents and movements in the development of sustainable energy technology, different available forms of renewable energies and today's economic crisis have led to introduction of renewable energy as a clean option that can have major rule in our common future (Taleghani et al., 2010).

For instance in India an option for small scale cashew nut processing was the renewable energy technologies which contribute to the sustainable development (Atul Mohod and Powar, 2010).

The major advantages of the renewable energy technologies at the moment include the simplicity of the technologies, ease of maintenance as well as their enhanced environmental friendliness over fossil fuel system (Sambo, 2005).

Solar energy is diffused in many parts of the world with the ambition to improve the situation in rural areas (Gustavsson, 2007). Solar energy as a renewable energy source is considered as an important alternative options for farmers. In many developing countries, solar energy has the potential to improve the living conditions of rural households and contribute to the country's future energy security.

Corresponding Author:Seyed Jamal F.Hosseini, Department of Agricultural Islamic Azad University, Science and Research Branch, Extension and Education, Tehran, Iran 
Am. J. Agri. \& Biol. Sci., 6 (1): 99-104, 2011

Particularly in rural areas, solar related technologies represent viable small-scale sources of renewable energy. Photovoltaic systems are portable, increasingly affordable and require minimal maintenance. Photovoltaic systems may be used by an individual households or may be linked together to form a grid with sufficient energy production to power an entire community (Gueye et al., 2004).

India like many developing countries, at the household level, traditional burning of biomass or use of inefficient technologies for domestic applications like lighting is common, triggering concerns related to fuel or technology switching. In Uttam Urja, it focuses on opportunities to promote cleaner energy options through delivering improved energy efficiency (Rehman et al., 2010).

Bangladesh is another example. Experiencing a gradual shift towards exploring renewable energy resources as a driving force for rural development. A few public sector and non-government organizations have started to develop Renewable Energy Technology (RET) projects in rural areas. The lessons learnt from different demonstrations of RET projects reveal that with careful forward planning renewable energy can provide far-reaching economic, environmental and social benefits to people living in remote rural areas in Bangladesh (Mondal et al., 2010). The use of solar photovoltaic systems of 25-50 $\mathrm{W}^{\mathrm{P}}$ (frequently called solar home systems, or SHSs) has been spreading fast in the rural areas of Sri Lanka as a source of energy. The large-scale penetration of solar home systems in Sri Lanka has helped rural communities both in terms of improved socio-economic conditions and reduced adverse environmental impacts, contrary to the belief that the financial burden of such systems imposed on the families outweighs the benefits (Wijayatunga and Attalage, 2005).

However, the development of renewable energy in rural areas faces several challenges such as slow adoption; lack of research and development; lack of awareness, slow dissemination of information; inadequate policy, poor integration of renewable energy in development plans and inadequate commitment by government (Mfume and Boon, 2008).

Sambo (2005) pointed out that one of the main barriers in adopting the renewable energy in Nigeria was lack of awareness of potential alternatives in energy resources.

Although research and development activities are still being seriously undertaken in various aspects of renewable energy utilization, a number of the technologies have since been shown to be feasible and ready for adoption (Sambo, 2005).
In a study about localization of new energies concluded that informing rural population about benefits of new energies would accelerate the speed of adoption in rural areas of Iran.

However, adopting is rarely instantaneous; the technology has to be taught and learned, adapted to experience and integrated into production. As is often the case with technological innovation, potential and expectations can outpace reality (Gelb and Bonati, 1998).

The adoption of any new technology and innovations has not been an easy task and it is usually not spontaneous, the technology has to be taught and learned to adopted to existing experience and integrated into production. As is often the case with technologicalinnovation potential and expectations can outpace reality (Gelb and Bonati, 1998).

The issue is not only the access to technology, but it is equally critical to provide training, tools and guidance to make rural population aware of what technology can do for them and what they can do with technology (Hosseini et al., 2009).

Several parameters have been identified as influencing the adoption behavior of farmers and social scientists investigating farmers who adopt the biotechnology showing the demographic variables, technology characteristics, information source, knowledge, awareness, attitude and group influence affect adoption behavior (Oladele, 2005).

A wide range of economic, social, physical and technical aspect of farming influences adoption of agricultural production technology. Wheeler (2005) citing Rogers and Pannell pointed the factors which influence the adoption of new innovations by farmers. She mentioned factors such as perception about risk and profitability; uncertainty and certainty about adoption; amount of required information and attitude about risk and uncertainty.

Agricultural extension by its nature has an important role in promoting the adoption of new technologies and innovations. Extension organizations have a key role in brokering between providers of technologies and farmers.

Agricultural extension and education has the highest economic impact and sustainability in agriculture by providing information to increase farmer's awareness, knowledge, adoption and productivity (Hosseini et al., 2010).

The extension-teaching methods are the tools and techniques used to create situations in which communication can take place between the rural people and the extension workers. They are the methods of extending new knowledge and skills to the rural people by drawing their attention towards them, arousing their 
Am. J. Agri. \& Biol. Sci., 6 (1): 99-104, 2011

interest and helping them to have a successful experience of the new practice.

The extension teaching methods can be classified based on their use: individual contacts, group contacts and mass contacts. Extension-teaching methods are also classified according to their forms, such as written, spoken and audio-visual.

The average annual solar radiation in Iran due to special geographical location is 5 kilowatt hours per day and this figure compared with other countries is very significant. Therefore, using solar energy in different parts of the country, especially in the desert regions could be an efficient energy option.

In 2003, government of Iran with cooperation of UNDP and Global Environmental Fund started the carbon sequestration project in Hussain Abad region of South Khorasan Province near the border with Afghanistan.

The project area is about 144000 hectares and the goal of project is to reduce degradation of pastures by promoting solar energy through a participatory process

This project through the mobilization of local communities will strengthen the community, social, human, financial and natural/environmental conditions of the region. An important component of this project is to promote the utilization of solar energy through empowerment of rural population.

The research question for this study is: what is the role of extension in adopting solar energy by rural population? The main focus of this study is to find out the role of extension in adopting solar energy in rural areas by participants in carbon sequestration project.

\section{MATERIALS AND METHODS}

The methodology used in this study involved a combination of descriptive and quantitative research and included the use of correlation, regression and descriptive analysis as data processing methods. The total population for this study was 310 residents of Hussain Abad who used solar energy for heating purposes. Data were collected through interview schedules.

A series of in-depth interviews were conducted with some senior experts in the Departments of Energy and Agriculture in South Khorasan Province to examine the validity of questionnaire. A questionnaire was developed based on these interviews and relevant literature. The questionnaire included both open-ended and fixed-choice questions. The open-ended questions were used to gather information not covered by the fixed-choice questions and to encourage participants to provide feedback.
Measuring respondents' attitudes towards role of extension in adopting solar energy has been achieved largely though structured questionnaire surveys. The final questionnaire was divided into several sections. The first section was designed to gather information about personal characteristics of respondents. The second section was designed to measure the attitudes of respondents about the role of carbon sequestration project in protecting the pastures. The respondents were asked to indicate their agreements by marking their response on a five point Likert-type scale. The next section explored the impact of solar energy on preventing the degradation of pastures and respondents were asked to indicate their opinion in a 5-point Likert format with responses from 1-completely disagree to 5completely agree. Further section dealt with questions about satisfaction about solar energy. The last section was about knowledge regarding the benefits of solar energy. The variables and their measurement scale are presented in Table 1.

\begin{tabular}{ll}
\multicolumn{2}{l}{ Table 1: Variables and their measurement scale } \\
\hline Variables & Measurement scale \\
\hline $\begin{array}{l}\text { Satisfaction about } \\
\text { solar energy }\end{array}$ & Five- point Likert \\
Knowledge about & \\
solar energy benefits & Five- point Likert \\
Tendency toward using & \\
solar energy & Tendency toward using \\
Impact of extension & solar energy \\
Activities in adopting & Five- point Likert \\
Solar energy & \\
Marital Status & \\
Age & Categorial \\
Educational Level & Categorial \\
Occupation & Categorial \\
\hline
\end{tabular}

Table 2: Demographic profile of respondents

\begin{tabular}{lcc}
\hline Demographic variables & Number & $\begin{array}{l}\text { Percentage } \\
\text { (\%), } \mathrm{n}=310\end{array}$ \\
\hline Age (years) & 19 & 6.1 \\
Less than 20 & 56 & 18.1 \\
$20-26$ & 79 & 25.5 \\
$27-33$ & 46 & 14.8 \\
$34-40$ & 12 & 10.3 \\
$36-40$ & 47 & 15.2 \\
$41-47$ & 26 & 8.4 \\
$48-54$ & 16 & 5.2 \\
55-61 & 21 & 6.8 \\
More than 61 & & \\
Mean= 36 years & & \\
Education & 137 & 44.2 \\
Illiterate & 116 & 37.4 \\
Elementary & 40 & 12.9 \\
Secondary & 8 & 2.6 \\
High School & 9 & 2.9 \\
Diploma & 7 & 6.1 \\
Professional & 3 & 2.6 \\
Bachelors & & \\
Occupation & 104 & 33.5 \\
Livestock owner & 167 & 53.9 \\
Farmers & 39 & 12.6 \\
Others & &
\end{tabular}


Am. J. Agri. \& Biol. Sci., 6 (1): 99-104, 2011

Content and face validity were established by a panel of experts consisting of faculty members at Islamic Azad University, Science and Research Branch and some specialists in the Department of Energy in South Khorasan Province. Minor wording and structuring of the instrument were made based on the recommendation of the panel of experts.

A pilot study was conducted with 25 persons who had not been interviewed before the earlier exercise of determining the reliability of the questionnaire for the study. Computed Cronbach's Alpha score was 75.0\%, which indicated that the questionnaire was reliable.

Dependent variable in the study included adopting solar energy which was measured by perception of respondents. The independent variables in this research study were the knowledge of respondents about benefits of solar energy, tendency toward using solar energy, extension activities, age, educational level and satisfaction about solar energy. For measurement of correlation between the independent variables and the dependent variable correlation coefficients have been utilized and include spearman test of independence.

\section{RESULTS}

The results of descriptive statistics indicated that the 208 respondents were male and 102 were females with average age of 36 years old and more than 44 percent were illiterate. More than half of respondents indicated that their main occupation was farming (Table 2).

Table 3 shows the means of respondents' views about the satisfaction with using solar energy and interested in using solar energy in the future.

Table 3: Means of Respondents' Views about satisfaction with solar energy and tendency toward using it ( 1 = very little; 5 = very much)

\begin{tabular}{ll}
\hline Statement & Mean \\
\hline Satisfaction with & 4.39 \\
Using solar energy & 4.58 \\
Interested in using & \\
Solar energy in future & \\
\hline
\end{tabular}

Table 4: Means of respondents' views about the extension activities which help them to adopt solar energy ( 1 = Too little; $5=$ Too much)

\begin{tabular}{lll}
\hline & Mean and standard deviation \\
Methods & Mean & SD \\
\hline Contact with extension agents & 4.21 & 0.899 \\
Lecture & 3.71 & 1.077 \\
Educational classes & 3.66 & 1.184 \\
Visiting the sample sites & 3.58 & 1.230 \\
Educational films and slides & 3.24 & 1.330 \\
Extension /education publications & 3.18 & 1.354 \\
TV and radio programs & 2.85 & 1.240 \\
\hline
\end{tabular}

As can be seen from this table, respondents were very much satisfied with using solar energy (mean = 4.39) and very much have tendency toward using solar energy in the future (mean $=4.58$ ).

The perception of respondents about the extension activities which help them to adopt solar energy was displayed in Table 4. The highest mean refers to contact with extension agents (mean $=4.21$ ) and the lowest mean refers to TV and radio program (mean $=2.85$ ).

Spearman coefficient was employed for measurement of relationship between independent variables and dependent variable. Table 5 displays the

Table 5: Correlation measures between independent variables and role of solar energy in adopting solar energy

\begin{tabular}{|c|c|c|c|}
\hline \multirow{2}{*}{$\begin{array}{l}\text { Independent variables } \\
\text { Age }\end{array}$} & \multirow{2}{*}{$\begin{array}{l}\text { Dependent variable } \\
\text { Adopting } \\
\text { Solar energy }\end{array}$} & \multicolumn{2}{|l|}{$\mathrm{r}$} \\
\hline & & 0.106 & 0.062 \\
\hline Educational level & $\begin{array}{l}\text { Adopting } \\
\text { Solar energy }\end{array}$ & 0.090 & 0.114 \\
\hline Knowledge about & $\begin{array}{l}\text { Adopting } \\
\text { Solar energy }\end{array}$ & $0.280 * *$ & 0.000 \\
\hline Benefits of solar energy & & & \\
\hline Tendency toward using & $\begin{array}{l}\text { Adopting } \\
\text { Solar energy }\end{array}$ & 0.064 & 0.261 \\
\hline Solar energy & & & \\
\hline Knowledge about carbon & $\begin{array}{l}\text { Adopting } \\
\text { Solar energy }\end{array}$ & $0.147 *$ & 0.010 \\
\hline Sequestration & & & \\
\hline Satisfaction about solar & $\begin{array}{l}\text { Adopting } \\
\text { Solar energy }\end{array}$ & 0.090 & 0.115 \\
\hline Energy & & & \\
\hline Contact with extension & $\begin{array}{l}\text { Adopting } \\
\text { Solar energy }\end{array}$ & $0.223^{* *}$ & 0.000 \\
\hline Agents & & & \\
\hline Lecture & $\begin{array}{l}\text { Adopting } \\
\text { Solar energy }\end{array}$ & $0.423 * *$ & 0.000 \\
\hline Educational classes & $\begin{array}{l}\text { Adopting } \\
\text { Solar energy }\end{array}$ & $0.283 * *$ & 0.000 \\
\hline Visiting sample sites & $\begin{array}{l}\text { Adopting } \\
\text { Solar energy }\end{array}$ & $0.377^{* *}$ & 0.000 \\
\hline $\begin{array}{l}\text { Educational films and } \\
\text { Slides }\end{array}$ & $\begin{array}{l}\text { Adopting } \\
\text { solar energy }\end{array}$ & $0.463^{* *}$ & 0.000 \\
\hline $\begin{array}{l}\text { Extension and education } \\
\text { Publication }\end{array}$ & $\begin{array}{l}\text { Adopting } \\
\text { solar energy }\end{array}$ & $0.460 * *$ & 0.000 \\
\hline TV and radio programs & $\begin{array}{l}\text { Adopting } \\
\text { solar energy }\end{array}$ & $0.344 * *$ & 0.000 \\
\hline
\end{tabular}

Table 6: Multivariate Regression Analysis (Role of extension in adopting solar energy as dependent variable).

\begin{tabular}{|c|c|c|c|c|}
\hline & B & Beta & $\mathrm{T}$ & Sig. \\
\hline Constant & 6.412 & -------- & 3.408 & 0.001 \\
\hline $\begin{array}{l}\text { Educational films } \\
\text { And slides }\end{array}$ & 1.375 & 0.265 & 4.198 & 0.000 \\
\hline $\begin{array}{l}\text { Contact with } \\
\text { Extension agents }\end{array}$ & 1.440 & 0.216 & 4.312 & 0.000 \\
\hline Visiting sample sites & 0.441 & 0.150 & 3.094 & 0.002 \\
\hline Lectures & 1.340 & 0.175 & 2.863 & 0.004 \\
\hline
\end{tabular}


Am. J. Agri. \& Biol. Sci., 6 (1): 99-104, 2011

results which show that there were relationship between perception of respondents about role of extension in adopting solar energy as dependent variable and independent variables.

Table 6 shows the result for regression analysis by stepwise method. Independent variables that were significantly related to perception of respondents about role of extension in adopting solar energy were entered. The result indicates that $30 \%$ of the variance in the perception of respondents about role of extension in adopting solar energy could be explained by using educational films and slides, contacting with extension agents, visiting sample sites and providing lectures.

\section{DISCUSSION}

The perception of respondents about the role of extension in adopting solar energy was discussed in this article. As the regression analysis showed, the knowledge about benefits of solar energy, interested about solar energy and satisfaction about solar energy caused $31 \%$ of variance on the perception of respondents regarding the role of solar energy in protecting pastures. This result is consistent with conclusion in which knowledge about benefits of solar energy have impact on adopting this type of energy.

Based on the results of the mean score, respondents indicated that the main factor influencing them to adopt the solar energy was their interests about natural resources. Wijayatunga and Attalage (2005) indicated that adoption of solar energy in Sri Lanka resulted in improving natural resources and reducing the environmental destruction.

The results demonstrated that respondents preferred individual teaching methods compared with group and mass methods. Although all extension agents use a variety of teaching methods, they generally tend to use more individual methods than the other agents. Farm visits and on-farm demonstrations model the early farm demonstration method of providing researchbased recommendations to the local producer.

The result of this study is consistent with Okunade (2007) conclusion in which skill is better acquired through group contact methods. These methods have the nature of practical demonstration which will help the clientele from desire stage through conviction and probably into taking action. The individual contact method and mass method is considered to be important tools to acquire knowledge. This may be as a result of the nature of the methods of giving information and deeper understanding of the innovation concerned.

In a study about selecting the appropriate teaching methods in Egypt reported that the most preferred extension methods concerning knowledge change were mass methods. The respondents pointed out in this study that the most preferred methods related to skill change were this method.

\section{CONCLUSION}

The results also show that authorities should explore ways to increase the participation of the rural population in planning, implementing and evaluation of solar energy. The lack of support from respondents may hinder the progress in the sustainability of solar energy. In Bangladesh, participation of rural population through non governmental organizations has developed renewable energy technology and this has resulted economic, environmental and social benefits in rural areas (Mondal et al., 2010).

The results demonstrated that success of solar energy will depend on the informing population about benefits and in this regard the authorities should provide accurate and on time information.

There is no single and appropriate intervention for developing and protecting solar energy in rural areas and in view of the numerous and varied constraints and opportunities, there is need to develop location- specific strategies.

\section{REFERENCES}

Mohod, A., S. Jain and A.G. Powar, 2010. Energy Option for Small Scale Cashew Nut Processing in India. Ene. Res. J., 1: 47-50. DOI: 10.3844/erjsp.2010.47.50

Gelb, E.M. and G. Bonati, 1998. Evaluating internet for extension in agriculture. J. Agri. Edu. Exten., 5: 211-216. DOI: 10.1080/13892249885300321

Gueye, A., J. McNary and J. Okai, 2004. Solar Energy and Rural Development: Constraints and Insights from the Developing World. Solar Energy Industries Association, Washington, D. C. http://www.gwu.edu/ oid/Solar_Energy.pdf

Gustavsson, M., 2007. Educational Benefits from Solar Technology- access to solar electric services and changes in children's study routines, experiences from eastern province Zambia. Ener. Pol., 2: 1292-1299. DOI:10.1016/J.ENPOL.2006.03.019

Hosseini, S.J., M. Niknami and M.Chizari, 2009. To determine the challenges in the application of ICTs by the agricultural extension service in Iran. J. agr. Ext. Rura. Deve., 1: 27-30. http://www.academicjournals.org/jaerd/PDF/Pdf20 09/Oct/Hosseini\%20et\%20al.pdf 
Hosseini, S.J., Y. Khorsand and S. Shokri, 2010. Extension mechanisms influencing the adoption of sprinkler irrigation system in Iran. Oze. J. App. Sci., $1:$

11-17. http://ozelacademy.com/OJAS_v3n1_2.pdf

Mfume, O. and E.K. Boone, 2008. Promoting renewable energy technologies for rural development in Africa: Experiences of Zambia. J. Hum. $\quad$ Eco., 24 : 175-189. http://www.krepublishers.com/02-

Journals/JHE/JHE-24-0-000-000-2008-Web/JHE24-3-000-000-2008-Abst-PDF/JHE-24-3-175-081808-Mfune-O/JHE-24-3-175-08-1808-Mfune-O-Tt.pdf

Mondal, A.H., L.M. Kamp and N.I. Pachova, 2010. Drivers, barriers and strategies for implementation of renewable energy technologies in rural areas in Bangladesh-an innovation system analysis. Ener. Pol., 38: 4626-4634. $\quad$ DOI: 10.1016/J.ENPOL.2010.04.018

Oladele, O.I., 2005. A Tobit analysis of propensity to discontinue adoption of agricultural technology among farmers in Southwestern Nigeria. J. of Central. Euro. Agric. 6:249-254. http://www.agr.hr/jcea/issues/jcea6-3/pdf/jcea63-7.pdf

Rehman, I.H., A. Kar, R. Raven, D. Singh and J. Tiwari et al., 2010. Rural energy transitions in developing countries. A case of the uttam urja initiative in India. Environ. Sci. Pol., 4: 303-311. DOI: 10.1016/j.envsci.2010.03.012
Sambo, A.S., 2005. Renewable energy for rural development. A Nigerian Perspective. ISESCO Sci. Technol. Visi., 1: 12-22. http://www.isesco.org.ma/ISESCO_Technology_V ision/NUM01/A.S.Sambo/A.S.Sambo.pdf

Taleghani, M., H.R. Ansari and P. Jennings, 2010. Renewable energy education for architects: Lessons from developed and developing countries. Int. J. Sust. Ener., 29: 105-115. DOI: 10.1080/14786460903440714

Van Campen, B., D. Guidi and G. Best, 2000. Solar Photovoltaics for sustainable agriculture and rural development. 1st Edn., United Nations Food and Agriculture, Rome, pp: 77.

Wheeler, S., 2005. Factors Influencing Agricultural Professionals' Attitudes towards Organic Agriculture and Biotechnology. Center for regulation and market analysis. University of South Australia. http://een.anu.edu.au/e05prpap/wheeler.pdf

Wijayatunga, P.D.C. and R.A. Attalage, 2005. Socioeconomic impact of solar home systems in rural Sri Lanka: A case-study. Ener. Sust. Dev., 9: 5-9. DOI: 10.1016/S0973-0826(08)60487-1 